\title{
Peran Servant Leadership Dalam Meningkatkan Kepuasan Dan Loyalitas Karyawan Pada Industri Manufaktur
}

\author{
${ }^{1}$ Beben Saputra, ${ }^{2}$ Rina Anindita \\ Universitas Esa Unggul, Jakarta, Indonesia \\ Email : ${ }^{2}$ rina.anindita@esaunggul.ac.id
}

(Diterima: Juli 2021; Direvisi: Juli 2021; Dipublikasikan: September 2021)

\begin{abstract}
ABSTRAK
Harapan seorang karyawan mempunyai seorang pemimpin yang dapat melayani mereka dengan baik, Seorang memimpin harus mampu melayani bawahannya dengan cara menempatkan kebutuhan karyawan sebagai prioritas, pentingnya menghargai seseorang, dan membatu orang lain dalam mencapai tujuan. Penelitian ini bertujuan untuk mengetahui ukuran yang tepat untuk variabel servant leadership, dan mengetahui peran servant leadership dalam meningkatkan kepuasan kerja dan loyalitas karyawan. penelitian ini menggunakan responden sebanyak 300 karyawan pada perusahaan manufaktur yang memproduksi sepatu di provinsi banten, penelitian ini menggunakan kuisioner yang disebarkan pada bulan November - Desember 2019. Data analisis yang digunakan dalam penelitian ini adalah Structural Equation Model (SEM). Hasil penelitian ini menunjukkan bahwa ukuran yang tepat untuk servant leadership adalah empowerment, standing back, authenticity, humility, dan stewardship, terdapat pengaruh servant leadership terhadap loyalitas karyawan, terdapat pengaruh servant leadership terhadap kepuasan kerja dan terdapat pengaruh kepuasan kerja terhadap loyalitas.
\end{abstract}

Kata Kunci: Servant Leadership, Kepuasan Kerja, Loyalitas Karyawan 


\section{PENDAHULUAN}

Karyawan merupakan sumber daya penting untuk hampir semua organisasi, karena mereka mewakili investasi penting dalam hal perekrutan, pelatihan, bonus, dan rencana perawatan kesehatan. Banyak perusahaan mengembangkan manfaat dari program pelatihan, penilaian kinerja dan sistem kerja berdasarkan pada prinsip peraturan perusahaan. Biasanya pedoman ini ditujukan untuk mengembangkan tenaga kerja yang loyal karena ini mengarah pada masa kerja yang lebih luas. Semakin lama seorang karyawan bekerja untuk perusahaan, maka semakin berharga karyawan tersebut (Pandey \& Khare,2012).

Perusahaan menganggap bahwa karyawan merupakan aset yang sangat berharga bagi perusahaan untuk terus bertahan dan tetap produktif di perusahaanya. Berbagai cara untuk mempertahankan dan meningkatkan kemampuan karyawan sebagai upaya dukungan perusahaan kepada karyawan untuk lebih baik dan memberikan kesempatan kepada karyawan untuk terus berkembang dan merasa nyaman di perusahaan tempat ia bekerja, namun perusahaan tetap dihadapkan pada kesulitan dalam mempertahankan karyawan di dalam organisasi, karena loyalitas dalam perusahaan harus tetap dipertahankan.

Cara meningkatkan loyalitas karyawan adalah salah satu masalah paling sulit saat ini yang mengganggu para pemimpin perusahaan. Beberapa cara diusulkan untuk memecahkan masalah ini, di antaranya meningkatkan gaya kepemimpinan yang merupakan perspektif kunci, gaya kepemimpinan menentukan hubungan antara pemimpin dan karyawan (Ding, Lu, Song, \& Lu, 2012). Loyalitas karyawan dan kepuasan kerja karyawan telah dijadikan sebagai masalah penting dan diperioritaskan perusahaan, meningkatkan kinerja dan semangat kerja karyawan yang diharapkan perusahaan dapat memanfaatkan dan mengendalikan sumber daya manusia dengan baik (Ding et al. 2012). Kemampuan memberdayakan karyawan di dalam perusahaan dengan baik, mampu menempatkan karyawan di tempat yang tepat sesuai kemampuan dan minat tanpa mengabaikan nilai-nilai etika pemenuhan kebutuhan dan harapan karyawan secara psikologis, maka karyawan semakin lama merasa nyaman dan senang di dalam pekerjaanya, sehingga mampu bertahan berada di perusahaan dalam waktu yang lama. Menurut Mitterer (2017) Seorang pemimpin yang baik sangat diharapkan oleh banyak karyawan. Ketika karyawan diangkat menjadi pemimpin maka karyawan akan mengharapkan bahwa pemimpin tersebut adalah pemimpin yang baik dan dapat mengayomi terhadap siapapun yang ada dibawah kepemimpinannya.

Menurut Johnson (2008) pada industri dirgantara menyatakan bahwa servant leadership mempunyai hubungan dengan kepuasan kerja, dan hal yang sama yang dilakukan oleh Donghong et al. (2012) di sektor pendidikan menunjukkan bahwa servant leadership secara signifikan berkorelasi positif dengan loyalitas karyawan, kepuasan kerja karyawan ditemukan memainkan peran mediasi dari total efek antara servant 
leadership. Peneltian yang dilakukan oleh Hashim, Khan, Ullah \& Yasir (2017) pada universitas swasta di Pakistan menyatakan bahwa servant leadership berpengaruh positif dan signifikan terhadap loyalitas karyawan, kemudian Anderson (2005) pada salah satu organisasi pendidikan agama yang berkantor pusat di wilayah gunung rocky menyatakan bahwa servant leadership mempunyai korelasi yang signifikan dengan kepuasan kerja. Disisi lain, penelitian Amadeo (2008) di Rumah Sakit juga menunjukkan bahwa servant leadership mempunyai hubungan dengan kepuasan kerja, sementara itu Johnson (2008) pada industri penerbangan di AS menyatakan bahwa servant leadership berhubungan positf terhadap kepuasan kerja. Menurut Noor \& Jamil (2014) pada sektor pemerintahan menyatakan bahwa kepuasan kerja karyawan mempunyai pengaruh positif dan siginifikan terhadap loyalitas karyawan,dan hal yang sama yang diungkapkan oleh Hussain (2010) pada indutri perhotelan menyatakan bahwa kepuasan kerja karyawan mempunyai pengaruh terhadap loyalitas karyawan. Selanjutnya, Lee (2008) menyatakan bahwa leadership empowerment mempengaruhi kepuasan kerja dan loyalitas karyawan, kepuasan kerja mepengaruhi loyalitas karyawan,dan kemudian Georgolopoulos, Papaloi \& Loukorou (2018) menyatakan bahwa servant leadership berhubungan positif terhadap kepuasan kerja.

Menurut Akdol \& Arikboga (2017) pada perusahaan sektor Teknologi dan Informasi menyatakan bahwa servant leadership mempunyai hubungan antara kepuasan kerja yang dimediasi oleh LMX (Leader Member Exchange), selanjutnya Mahdy, Harthi \& Din (2016) menyatakan bahwa servant leadership mempunyai hubungan dengan kepuasan kerja. Kemudian Farman, Afridi \& Haider (2019) pada universitas swasta menyatakan bahwa servant leadership mempunyai hubungan positif dan signifikan dengan loyalitas karyawan, hal ini juga diungkapkan oleh Mitterer (2017) pada rumah sakit menyatakan bahwa servant leadership mempunyai pengaruh terhadap kepuasan kerja, servant leadership mempunyai pengaruh terhadap Turnover Intention. Menurut Onsardi, Asmawi \& Abdullah (2017) pada sektor pendidikan menyatakan bahwa ada pengaruh positif kompensasi, empowerment, dan kepuasan kerja terhadap loyalitas karyawan, ada pengaruh positif kompensasi, dan empowerment terhadap loyalitas karyawan, dan ada pengaruh positif terhadap kompensasi terhadap empowerment, kemudian menurut Frempong, Agbenyo \& Darko (2018) pada industri Pertambangan, Keuangan dan Manufaktur menyatakan bahwa kepuasan kerja mempunyai pengaruh yang siginifikan terhadap loyalitas dan komitmen dan menurut Guillaume, Honeycutt \& Austin (2013) penelitian yang dilakukan di salah satu universitas menyatakan bahwa servant leadership berpengaruh terhadap kepuasan kerja.

Penelitian terdahulu mengenai servant leadership, kepuasan kerja dan loyalitas karyawan sudah banyak dilakukan diantaranya oleh Johnson 
(2008), Donghong et al. (2012), Hashim, Khan, Ullah \& Yasir (2017), Anderson (2005), Amadeo (2008), Noor \& Jamil (2014), Hussain (2010), Lee (2008), Georgolopoulos, Papaloi \& Loukorou (2018), Akdol \& Arikboga (2017), Mahdy, Harthi \& Din (2016), Farman, Afridi \& Haider (2019), Mitterer (2017), Onsardi, Asmawi \& Abdullah (2017), , Guillaume, Honeycutt \& Austin (2013) dan Frempong, Agbenyo \& Darko (2018). Namun demikian penelitian tersebut tidak secara bersama-sama diteliti didalam satu penelitian dan objek penelitian yang dilakukan di idonesia pada perusahaan manufaktur sangat jarang sekali, selain itu dalam peneltian ini penulis menggunakan pengukuran yang berbeda dengan peneltian terdahulu pada setiap variabelnya. Sehingga penulis melihat masih diperlukan kembali pemahaman mengenai servant leadership, kepuasan kerja dan loyalitas karyawan dan menjadi saran bagi objek penelitian tersebut.

Berdasarkan kesenjangan penelitian diatas maka tujuan dari penelitian yang ingin dicapai adalah mengetahui tentang bagaimana ukuran yang tepat untuk variabel servant leadership dan dampak servant leadership dalam meningkatkan kepuasan kerja dan loyalitas karyawan pada industri manufaktur.

\section{TINJAUAN PUSTAKA}

\section{Servant Leadership}

Servant leadership pertama kali diusulkan pada 1977 oleh Gren- leaf. Dia percaya bahwa untuk menjadi seorang pemimpin, seseorang harus melayani bawahan dan yang terpenting adalah kesadaran pelayanan (Donghong et al., 2012). Menurut Giambatista, Mckeage \& Mccormick (2016) mendefinisikan servant leadership sebagai pemahaman dan praktek kepemimpinan yang menempatkan baik dari mereka yang dipimpin demi kepentingan diri pemimpin, kemudian menurut Woodruff (2004) servant leadership didefinisikan sebagai sikap memimpin orang lain dari perspektif penempatan tujuan organisasi, kebutuhan organisasi, dan kebutuhan orang-orang di atas kebutuhan dan keinginan pemimpin. Sedangkan menurut Amri, Hajji \& Alawaji (2016) mendefinisikan servamt leadership sebagai pendekatan holistik, multidimensi untuk kepemimpinan yang mencakup sisi rasional, emosional, etis, dan spiritual dari kedua pemimpin dan pengikut, dan Carter \& Baghurst (2014) mendefinisikan servant leadership adalah filosofi kepemimpinan, yang membahas masalah etika, pengalaman pelanggan, dan keterlibatan karyawan sambil menciptakan budaya organisasi yang unik, di mana baik pemimpin dan pengikut bersatu untuk mencapai tujuan organisasi tanpa kekuatan posisi atau otoritas. Menurut Dierendoick \& Nuijten (2011) terdapat delapan dimensi untuk mengukur Servant Leadership yaitu Empowerment, Standing back, Accountability, Forgiveness, Courage, Authenticity, Humility, dan Stewardship. 


\section{Kepuasan Kerja}

Menurut Nwachukwu, Chládková \& Olatunji (2018) kepuasan kerja adalah orientasi efektif yang dimiliki karyawan terhadap pekerjaannya, menurut Lu, While \& Barribal (2005) kepuasan kerja adalah perasaan global tentang pekerjaan seseorang atau sekelompok sikap yang terkait tentang berbagai aspek lingkungan kerja. Kemudian menurut Aziri (2011) kepuasan kerja adalah perasaan prestasi dan keberhasilan pekerja dalam pekerjaan,selanjutnya menurut Odebiye, Olauye \& Ogunleye (2013) kepuasan kerja dapat didefinisikan sebagai keadaan emosional yang menyenangkan yang dihasilkan dari penilaian pekerjaan seseorang, atau sikap terhadap pekerjaan seseorang. Sedangkan menurut Robbins \& Judge (2015) kepuasan kerja adalah perasaan positif tentang pekerjaan, yang dihasilkan dari evaluasi karakteristiknya, dan Asmawi, Onsardi \& Abdullah (2017) juga menjelaskan bahwa kepuasan kerja suatu keadaan emosional yang menyenangkan atau positif yang dihasilkan dari penilaian pekerjaan atau pengalaman kerja seseorang. Menurut Kowalik (2013) kepuasan kerja didefinisikan sebagai persepsi individu tentang pekerjaan yang memenuhi kebutuhan pribadi karyawan, dan menurut Meria (2018) kepuasan kerja adalah hasil dari persepsi karyawan mengenai seberapa baik pekerjaan mereka memberikan hal yang dinilai penting bagi mereka. Menurut Tanujaya

(2012) kepuasan kerja merupakan sikap umum yang merupakan hasil dari beberapa sikap khusus terhadap faktor-faktor pekerjaan, penyesuaian diri dan hubungan sosial individu di luar kerja,adapun menurut Heriyanti (2015) kepuasan atau ketidakpuasankaryawan tergantung pada perbedaan antara apa yang diharapkan. Sebaliknya, apabila yang didapat karyawan lebih rendah daripada yang diharapkan akan menyebabkan karyawan tidak puas. Kepuasan kerja yaitu kepuasan kerja merupakan suatu tanggapan emosional seseorang terhadap situasi dan kondisi kerja (Meria, 2019).

Menurut Moyes, Shao \& Newsome (2008) kepuasan kerja menggambarkan betapa senangnya seorang karyawan dengan posisi pekerjaannya. Bisa dibilang, kepuasan karyawan mengukur sejauh mana karyawan bahagia dengan pekerjaan mereka, sedangkan menurut Jr (2016) salah satu definisi lama dari kepuasan kerja menggambarkannya sebagai orientasi yang efektif pada bagian individu terhadap peran pekerjaan yang saat ini mereka tempati, Menurut Rojuaniah (2017) kepuasan kerja karyawan merupakan sikap karyawan terhadap bagaimana memandang pekerjaannya, sedangkan menurut Tanujaya (2014) kepuasan kerja merupakan sikap umum yang merupakan hasil dari beberapa sikap khusus terhadap faktorfaktor pekerjaan, penyesuaian diri dan hubungan sosial individu di luar kerja. Menurut Alpern et al. 
(2013) menyatakan terdapat tiga dimensi untuk variabel kepuasan kerja yaitu relationships with management and supervisors, job content, dan relationships with coworkers.

\section{Loyalitas Karyawan}

Banyak perusahaan memandang karyawan sebagai aset perusahaan dan kesetiaan karyawan menjadi sama pentingnya dengan masalah loyalitas pelanggan dalam industri bisnis. Meskipun perusahaan telah berusaha untuk memberikan dukungan atau peluang yang lebih baik kepada karyawan, mereka telah menghadapi kesulitan dalam mempertahankan karyawan dalam organisasi (McCan, \& Graves, 2008). Menurut Murali, Poddar \& Seema (2017) loyalitas karyawan didefinisikan sebagai pengabdian seseorang atau perasaan melekat pada objek tertentu, kemudian menurut Nippa \& Hornung (2014) loyalitas karyawan dapat didefinisikan sebagai ikatan yang kuat yang mengikat seorang karyawan ke perusahaannya bahkan ketika mungkin secara ekonomi tidak sehat baginya untuk tinggal di sana. Selanjutnya menurut Elegido (2013) loyalitas karyawan adalah komitmen yang disengaja untuk memajukan kepentingan terbaik dari perusahaan, dan menurut Wan (2007) loyalitas karyawan dapat didefinisikan sebagai keterikatan psikologis atau komitmen pada organisasi dan berkembang sebagai hasil dari peningkatan kepuasan.

Menurut Haar (2017) mendefinisikan loyalitas karyawan sebagai suatu cara yang optimis dalam meningkatkan kesetiaan terhadap perusahaan, sedangakan menurut Chen, Chen, Tsui \& Chiang (2016) mendefinisikan loyalitas karyawan sebagai perilaku aktif, baik melalui suara atau tindakan, yang mengekspresikan kebanggaan dan dukungan dalam organisasi. Kemudian menurut Fawwaz, Qudah, Yang \& Anjum (2018) loyalitas karyawan adalah jaminan emosional dari ambisi karyawan untuk terlibat dan tetap dengan konstan dan bertanggung jawab dengan organisasi, selanjutnya menururt Khuong, Linh \& Duc (2015) loyalitas karyawan adalah kekuatan pendorong utama di balik pengembangan organisasi yang berkelanjutan. Menurut Marcelino \& Correia (2015) loyalitas karyawan adalah perilaku warga organisasi yang mencerminkan kesetiaan kepada organisasi melalui promosi minat dan citra kepada orang luar, sedangkan menurut Yulianto \& Martina (2018) Loyalitas karyawan adalah sebuah keyakinan individu mengenai syarat dan kondisi dari perusahaan. Menurut Chauhan \& Mahajan (2013) terdapat satu dimensi loyalitas kerja yaitu stay with the organization.

Kinerja adalah hasil kerja secara kualitas dan kuantitas yang dicapai oleh seorang pegawai dalam melaksanakan tugasnya sesuai dengan tanggung jawab yang diberikan kepadanya (Mangkunegara, 2009:67). Konsep penilaian kinerja yang digunakan Dinas Kehutanan dan Perkebunan Kota Bogor mengukur kualitas 
kerja dari ketepatan waktu penyampaian laporan harian sedangkan kuantitas kerja di ukur dengan melihat pelaksanaan tugas pokok dan tugas tambahan. Sejalan dengan teori dari Miner (Sudarmanto, 2009:11-12), yang dijadikan sebagai tolak ukur dalam menilai kinerja, yaitu: kuantitas, kualitas, penggunaan waktu dalam bekerja dan kerjasama dengan orang lain dalam bekerja.

\section{METODE PENELITIAN}

\section{Populasi dan Sampel}

Penelitian dilakukan pada bulan November - Desember 2019, objek penelitian ini adalah karyawan tetap di perusahaan industri manufaktur yang memproduksi sepatu di provinsi banten, mereka adalah karyawan yang bekerja lebih dari 1 tahun dan jabatan mereka adalah staf, dan karyawan produksi, pernyataan kuesioner dalam penelitian ini sebanyak 60 pernyataan, sehingga jumlah sampel yang diambil dalam penelitian ini $(60 \times 5) \quad 300$ responden. Aspek yang diteliti adalah servant leadership kepuasan kerja, dan loyalitas karyawan.

\section{Metode Analisis Data}

Dalam penelitian ini terdapat satu variabel eksogen yaitu Servant Leadership dan dua variabel endogen yaitu Loyalitas Karyawan dan Kepuasan Kerja. Pengukuran variabel servant leadership menggunakan dimensi Dierendonck \& Nuijten (2011) yaitu Empowerment, Standing back, Accountability, Forgiveness, Courage, Authenticity, Humility, dan Stewardship, yang terdiri dari
30 pertanyaan, variabel kepuasan kerja menggunakan dimensi Alpern et al. (2013) yaitu relationships with management and supervisors, job content, dan relationships with coworkers, yang terdiri dari 18 pertanyaan dan selanjutnya variabel loyalitas karyawan menggunakan dimensi Chauhan \& Mahajan (2013) yaitu stay with the organization, yang terdiri 12 pertanyaan. Masing masing variabel di uji analisis faktor berdasarkan dimensi. Selanjutnya dari dimensi pengukuran tersebut yang ditampilkan dalam bentuk kuesioner, kemudian dilakukan uji validitas dan uji reliabilitas.

Menurut Prudon (2015)Uji validitas dilakukan dengan Confirmatory Factor Analysis, dengan melihat nilai KaiserMeyer-Olkin Measure of Sampling (KMO) dan Measures of Sampling Adequacy (MSA). Dalam tes ini nilai yang diperoleh harus lebih besar dari 0,5 yang berarti bahwa analisis faktor sesuai untuk digunakan, dan dapat diproses lebih lanjut. Sugiyono (2012) Uji reliabilitas nilai Alpha Cronbach lebih besar dari > 0,5 yang berarti reliabel, sehingga dapat dikatakan bahwa indikator semua variabel dapat dikatakan dipercaya sebagai alat pengumpulan data dalam penelitian ini.

Berdasarkan hasil analisis uji validitas dan reliabilitas menggunakan analisis faktor untuk variabel servant leadership dengan dimensi Empowerment, Standing back, Authenticity, Humility, dan Stewardship mempunyai nilai $\mathrm{KMO}>$ 0,5, Anti-Image Matrix 
(MSA) > 0,5, Component Matrix 1, dan nilai alpha cronbach's $>0,6$ sehingga analisi faktor pada variabel servant leadership dapat digunakan atau diterima, kemudian hasil analisis faktor variabel kepuasan kerja untuk dimensi relationships with management and supervisors, and job content mempunyai nilai KMO $>$ 0,5, Anti-Image Matrix (MSA) > 0,5, Component Matrix 1, dan nilai alpha cronbach's > 0,6 dengan demikian hasil analisi faktor pada variabel kepuasan kerja dapat digunakan atau diterima, dan selanjutnya untuk variabel loyalitas karyawaN dengan dimension stay with the organization mempunyai nilai $\mathrm{KMO}>0,5$, Anti-Image Matrix $($ MSA) > 0,5, Component Matrix 1, dan nilai alpha cronbach's $>0,6$ maka hasil nalisis faktor pada variabel loyalitas karyawan dapat digunakan atau diterima.

Metode analisis data pada penelitian ini menggunakan Confirmatory Factor Analysis (CFA) untuk mengetahui dimensi dan indikator dari servant leadership dan Structural Equation Modeling (SEM) untuk mengetahui hubungan variabel secara kompleks serta efeknya langsung atau tidak langsung dari satu atau beberapa variabel terhadap variabel lain. Hair et al. (2014) Proses pengambilan sampel dilakukan dengan menggunakan keseluruhan populasi dan jumlahnya memenuhi syarat untuk metode SEM Metode pengukuran datanya menggunakan skala likert dengan interval skala satu sampai lima.

\section{Hipotesis Penelitian}

\section{Hubungan Antara Servant Leadership Dengan Loyalitas Karyawan}

Beberapa cara yang diusulkan untuk memecahkan masalah loyalitas karyawan, yaitu di antaranya meningkatkan gaya kepemimpinan di dalam perusahaan dan itu menjadi perspektif kunci, maka sampai batas waktu tertentu, gaya kepemimpinan dapat menentukan hubungan antara pemimpin dengan karyawan. Untuk gaya kepemimpinan yang melayani (servant Leadership) ini, bukanlah orientasi pada tujuan individu karyawan, akan tetapi tujuan pemimpin yaitu mengutamakan dan mendahulukan kepentingan karyawan serta kebutuhan karyawan dari tujuan organisasi atau tujuan pribadi pemimpin, pemimpin yang baik akan memberikan ruang bagi karyawan untuk tumbuh dalam kariernya, dan akan mencari hal baru yang bisa dilakukan oleh karyawannya, loyalitas akan dapat terus terjaga jika diberikan kesempatan untuk mengembang kemampuan dan tanggung jawab (Mitterer, 2017). Servant leadership dianggap konsisten dengan perkembangan zaman dan berkelanjutan, serta memiliki dampak yang positif terhadap loyalitas karyawan (Donghong et al. 2012). Penelitian yang dilakukan oleh Haider, Afridi \& Farman (2019) servant leadership mempunyai pengaruh positif dan signifikan terhadap loyalitas karyawan. Kepercayaan karyawan secara sebagian memediasi hubungan antara 
kepemimpinan pelayan dan loyalitas karyawan, penelitian juga dilakukan oleh Hasyim, Khan, Ullah \& Yasir (2017) menyatakan bahwa Servant leadership mepunyai hubungan positif terhadap loyalitas karyawan, Berdasarkan ulasan diatas maka dapat dibuat hipotesis :

H1 : Servant Leadership yang baik akan meningkatkan Loyalitas Karyawan

\section{Hubungan Antara Servant Leadership Dengan Kepuasan Kerja}

Karyawan akan terdorong untuk aktif dalam menyampaikan ide, serta peduli pada keadaan perusahaan, kedekatan dan rasa simpati antara karyawan dan pemimpin akan tumbuh melalui sikap pemimpin yang terbuka, hal tersebut akan menumbuhkan rasa percaya karyawan terhadap pemimpin dan perusahaan. Pemimpin yang dipercaya oleh karyawan dan sikap pemimpin yang hormat dan menghargai akan mendorong karyawan untuk bekerja produktif dan merasa puas atas dirinya sendiri, bahkan karyawan akan merasa puas atas pekerjaannya, karyawan akan berusaha bekerja dengan baik, dan secara sukarela melakukan peran ekstra untuk mendukung efektivitas organisasi (Donghong et al. 2012). Penelitian yang dilakukan oleh Guillaume, Honeycutt \& Austin (2013) menunjukkan bahwa servant leadership mempunyai hubungan dengan kepuasan kerja, penelitian juga dilakukan oleh Donghong et al. (2012) menyatakan bahwa servant leadership mempunyai hubungan dengan kepuasan kerja. Kemudian penelitian yang dilakukan oleh Akdol \& Arikboga (2017) servant leadership mempunyai hubungan dengan kepauasan kerja Leader Member Exchange (LMX) sebagai mediasinya, selain itu penelitian juga dilakukan oleh Amadeo (2008) menyatakan bahwa servant leadership mempunyai hubungan yang kuat dengan kepuasan kerja. Hal yang sama yang dilakukan oleh Mitterer (2017) menyatakan bahwa servant leadership mempunyai hubungan dengan kepuasan kerja, penelitian juga dilakukan oleh Anderson (2005) menyatakan bahwa servant leadership mempunyai hubungan terhadap kepuasan kerja. Selanjutnya Georgolopoulos, Papaloi \& Loukorou (2018) menunjukkan hubungan positif yang kuat secara signifikan antara kepuasan kerja dan servant seadership, penelitian juga dilakukan oleh Johnson (2008) penelitian menunjukkan bahwa antara servant leadership dengan kepuasan kerja mempunyai hubungan yang positif. Hal serupa yang ddilakukan oleh Mahdy, Harthi \& Din (2016) hasil penelitian menunjukkan bahwa guru menunjukkan tingkat kepuasan kerja dan servant leadership, ada perbedaan signifikan berdasarkan jenis kelamin dan jenis sekolah di bidang penyembuhan emosional, promosi, dan sifat pekerjaan, dan Anderson (2005) hasil penelitian menunjukkan bahwa servant leadership mempunyai korelasi 
yang signifikan antara kepuasan kerja. Berdasarkan ulasan diatas maka dapat dibuat hipotesis :

H2 : Servant Leadership yang baik akan meningkatkan Kepuasan Kerja

\section{Hubungan}

Kepuasan Kerja

Antara Loyalitas Karyawan

Cara yang baik untuk memotivasi karyawan dan meningkatkan Loyalitas karyawan kepada perusahaan adalah melalui insentif dan penghargaan, jika seorang karyawan telah bersama perusahaan selama beberapa tahun tertentu, maka mereka harus diberi imbalan atas kesetiaan mereka, ketika karyawan merasa diperhatikan oleh perusahaan maka karyawan akan merasa puas dalam bekerja dan loyal kepada perusahaan (Murali, Poddar \& Seema, 2017). Menurut Allen \& Grisaffe (2001) dalam Vahid \& Domician (2019) kesetiaan dianggap sebagai situasi psikologis termasuk hubungan yang baik antara karyawan dan majikan, cara terbaik meningkat kepuasan kerja karyawan yaitu selalu meperhatikan kebutuhan dari karyawan, karyawan yang merasa puas akan membela perusahaannya dan karyawan akan memutuskan untuk tetap bekerja untuk perusahaan. Penelitian yang dilakukan oleh Noor \& Jamil (2014) menyatakan bahwa kepuasan kerja karyawan berpengaruh positif terhadap loyalitas karyawan, Hussain (2010) menyatakan bahwa kepuasan kerja mempunyai hubungan dengan loyalitas karyawan. penelitian juga dilakukan oleh Frempong, Agbenyo \& Darko (2018) menyatakan bahwa kepuasan kerja mempunyai hubungan yang signifikan terhadap loyalitas karyawan, kemudian penelitian Onsardi, Asmawi \& Abdullah (2017) menyatakan bahwa kepuasan kerja mempunyai pengaruh terhadap loyalitas karyawan, dan Lee (2008) menyatakan bahwa kepuasan kerja mepengaruhi loyalitas karyawan. Berdasarkan ulasan diatas maka dapat dibuat hipotesis :

H3 : Kepuasan Kerja yang tinggi akan meningkatkan Loyalitas Karyawan

Dari uraian di atas, dapat digambarkan model penelitian sebagai berikut :

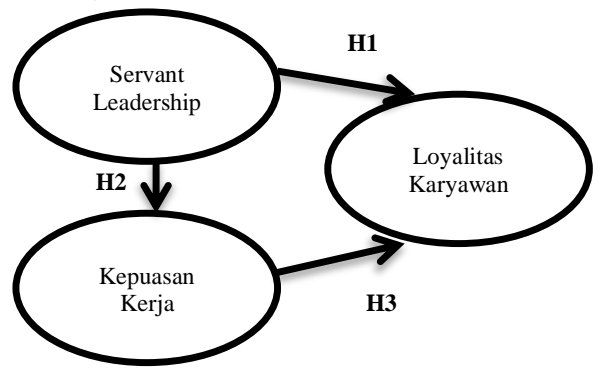

Gambar 1. Kerangka Penelitian

\section{HASIL PENELITIAN}

\section{Analisis Perbedaan Demografi Responden}

Analisis perbedaan demografi responden (jenis kelamin, usia, pendidikan terakhir, jabatan, dan masa kerja) dilakukan untuk mengetahui apakah terdapat perbedaan yang signifikan terhadap masing-masing variable yaitu servant leadership, kepuasan kerja, dan loyalitas karyawan, maka diperlukan suatu uji beda. 
Berdasarkan hasil analisis uji perbedaan demografi menggunakan uji ANOVA menunjukkan bahwa tidak ada perbedaan pada uji reponden, berdasarkan jenis kelamin, umur, pendidikan terakhir, jabatan, dan masa menunjukkan hasil homogeneity > 0,05 dan Anova > 0,05 .

Keseluruhan pada hasil uji ANOVA responden menujukkan bahwa tidak ada perbedaan sehingga jawaban responden bersifat homogeneity dan uji ANOVA dapat dilakukan yaitu pada jawaban responden berdasarkan jenis kelamin, usia, pendidikan terkahir, jabatan dan masa kerja terhadap servant leadership kepuasan kerja, dan loyalitas karyawan.

2. Uji Validitas dan Reliabilitas (Costruct)

Pada hasil pengukuran validitas konstruk, semua indikator pada variabel servant leadership,kepuasan kerja, dan loyalitas karyawan dapat diterima karenanilai factor loading memiliki kecocokan yang naik $(>0,50)$, dan nilai $t$ value lebih besar dari t-tabel $(1,96)$ pada level signifikansi $5 \%$. Selanjutnya uji reliabilitas konstruk memenuhi syarat nilai $\mathrm{CR}$ diatas 0,60 dan Nilai VE diatas 0,50 (Hair, at al 2013). Pada nilai CR semua memenuhi syarat reliable yaitu nilai diatas 0,60 , servant leadership (1,02), Kepuasan Kerja $(1,04)$, dan loyalitas karyawan $(1,07)$. Pada nilai VE semua memenuhi syarat reliabel yaitu nilai diatas 0,50 , untuk servant leadership $(1,35)$, kepuasan kerja
$(1,34)$, dan loyalitas karyawan $(1,36)$.

3. Analisis Uji Struktural

Analisi uji structural dat dilihat di dari nilai $\mathrm{R}^{2}$. Nilai $\mathrm{R}^{2}$ untuk masing-masing persamaan berfungsi untuk menunjukkan seberapa jauh variabel independen mampu menjelaskan dependen. Hasil analisi pertama yaitu secara bersama sama SL (Servant Leadership) mempengaruhi $\mathrm{KK}$ (Kepuasan Kerja) dengan nilai $\mathrm{R}^{2}$. sebesar 0,90. Artinya sebesar $90 \%$ varian dari SL (Servant Leadershp) dapat dijelaskan variabel KK (Kepuasan Kerja), sedangkan sisanya $10 \%$ dapat dijelaskan variabel lain yang tidak ada pada penelitian. Hasil analisis dua, yaitu secara bersama-sama KK (Kepuasan Kerja) dan SL (Servant Leadership) mempengaruhi LK (Loyalitas Karyawan) dengan nilai $\mathrm{R}^{2}$. sebesar 0,88. Artinya $88 \%$ varian dari LK (Loyalitas Karyawan) dapat dijelaskan oleh variabel KK (Kepuasan Kerja) dan SL (Servant Leadership), sedangkan sisanya $12 \%$ dapat dijelaskan oleh variabel lain yang tidak ada penelitian ini.

4. Analisis Kesesuain Seluruh Model

Dari analiss uji keseuaian semua pengujian menunjukkan kecocokan yang baik diantanya Chisquare, EVCI, AIC dan CAIC, fit index, dan Goodness of fit. Terdapat hasil marhginal fit pada critical N. Dari hasil analisi diatas, dapat disimpulkan bahwa uji kecocokan keselurahan model memenuhi syarat (good fit) hasil dapat dilihat pada lampiran 8 pada 
table 15). Selanjutnya penelitian ini menghasilkan path diagram T-

Value sebagai berikut

untuk mengetahui ketepatan

data tentang kesesuaian antara yang mau diukur dengan hasil pengukurannya.

Menurut

Sugiyono (2016) "Valid berarti terdapat kesamaan antara data yang terkumpul dengan data yang sesungguhnya". Sedangkan Ghozali (2013) berpendapat "Suatu kuesioner dikatakan valid jika pertanyaan pada kuesioner mampu untuk mengungkapkan sesuatu yang akan diukur oleh kuesioner tersebut". Untuk melakukan uji validitas dilihat nilai signifikansi 2 tailed dibandingkan dengan 0,05 dengan dengan ketentuan:

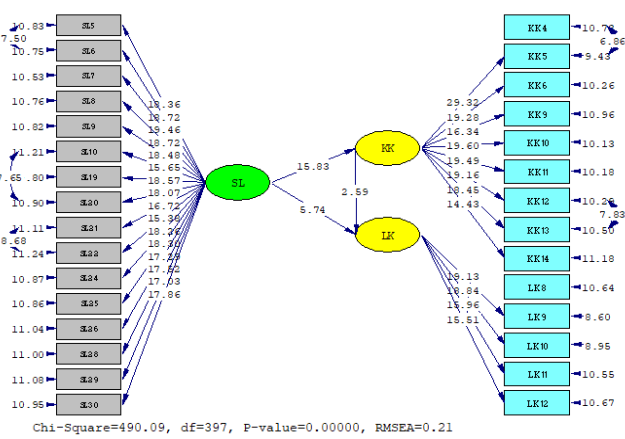

Gambar 2. Hasil Uji T-Value

Keterangan :0020x`Servant Leadership (SL), Kepuasan Kerja (KK), dan Loyalitas Karyawan (LK)

Berdasarkan gambar 2 path diagram T-Value merupakan hipotes dalam penelitian ini, tersaji dalam tabel pengujian hipotesis sebagai berikut :
Tabel 1. Hasil Pengujian Hipotesis Model Penelitian

\begin{tabular}{|c|c|c|c|}
\hline Hipotesis & $\begin{array}{c}\text { Pernyataan } \\
\text { hipotesis }\end{array}$ & $\begin{array}{c}T- \\
\text { Value }\end{array}$ & Keterangan \\
\hline $\mathrm{H}_{1}$ & $\begin{array}{c}\text { Servant } \\
\text { Leadership } \\
\text { yang baik } \\
\text { akan } \\
\text { meningkatkan } \\
\text { Loyalitas } \\
\text { Karyawan. }\end{array}$ & 5,74 & $\begin{array}{c}\text { Data } \\
\text { mendukung } \\
\text { hipotesis }\end{array}$ \\
\hline $\mathrm{H}_{2}$ & $\begin{array}{c}\text { Servant } \\
\text { Leadership } \\
\text { yang baik } \\
\text { akan } \\
\text { meningkatkan } \\
\text { Kepuasan } \\
\text { Kerja. }\end{array}$ & 15,83 & $\begin{array}{c}\text { Data } \\
\text { mendukung } \\
\text { hipotesis }\end{array}$ \\
\hline $\mathrm{H}_{3}$ & $\begin{array}{c}\text { Kepuasan } \\
\text { Kerja yang } \\
\text { tinggi akan } \\
\text { meningkatkan } \\
\text { Loyalitas } \\
\text { Karyawan. }\end{array}$ & 2,59 & $\begin{array}{c}\text { Data } \\
\text { mendukung } \\
\text { hipotesis }\end{array}$ \\
\hline
\end{tabular}

Sumber : Hasil Analisis Data SEM Lisrel

\section{PEMBAHASAN PENELITIAN}

HASIL

Dalam penelitian ini mempunyai 2 tujuan yaitu untuk mengetahui tentang bagaimana ukuran yang tepat untuk variabel servant leadership dan dampak servant leadership dalam meningkatkan kepuasan kerja dan loyalitas karyawan pada industri manufaktur. Untuk menjawab tujuan yang pertama, berdasarkan uji validitas dan reliabilitas menggunakan analisis faktor menunjukkan bawah untuk variabel servant leadership dengan dimensi Empowerment, Standing back, Authenticity, Humility, dan Stewardship merupakan ukuran yang tepat untuk variabel servant leadershipkarena melihat dari pertanyan-pertanyaan pada setiap dimensi, yang diberikan kepada responden mungkin dapat menggambarkan keadaan responden terhadap pemimpinnya. 
Kedua Dalam penelitian ini terdapat hasil yang menunjukkan bahwa servant leadership mempunyai pengaruh terhadap loyalitas karyawan. artinya seorang pemimpin yang mempunyai pelayaan yang baik terhadap karyawannya, akan mempengaruhi karyawannya untuk loyal terhadap pekerjaan mereka. hasil penelitian ini sejalan dengan dengan penelitian yang dilakukan oleh Donghong et al. 2012 disektor pendidikan menyimpukan bahwa servant leadership secara signifikan berkorelasi positif dengan loyalitas karyawan, kepuasan kerja karyawan ditemukan memainkan peran mediasi dari total efek antara servant leadership. Selanjutnya penelitian ini juga didukung oleh Hashim, Khan, Ullah \& Yasir (2017) melakukan penelitian di salah satu universitas swasta di kota Pakistan menyatakan bahwa servant leadership berpengaruh positif dan signifikan terhadap loyalitas karyawan. Kemudian Lee (2008) penelitian yang dilakukan di universitas menyatakan bahwa leadership empowerment mempengaruhi kepuasan kerja dan loyalitas karyawan, kepuasan kerja mepengaruhi loyalitas karyawan. Hal yang sama dilakukan oleh Farman, Afridi \& Haider (2019) penelitian yang dilakukan di Universitas swasta di Peshawar menyatakan bahwa servant leadership mempunyai hubungan positif dan signifikan dengan loyalitas karyawan.

Hasil pengujian juga menunjukkan bahwa servant leadership dan kepuasan kerja mempunyai pengaruh yang artinya data mendukung hipotesis. Hal ini menunjukkan bahwa seorang pemimpin yang baik akan meningkat kepuasan kerja meningkat. Penelitian ini sejalan dengan yang dilakukan oleh Johnson (2008) penelitian di industri dirgantara menunjukkan bahwa servant leadership berhubungan terhadap kepuasan kerja. Kemudian Donghong et al. (2012) melakukan penelitan di sektor pendidikan menunjukkan bahwa servant leadership secara signifikan berkorelasi positif dengan loyalitas karyawan, kepuasan kerja karyawan ditemukan memainkan peran mediasi dari total efek antara servant leadership. Kemudian Anderson (2005) penelitian pada Church Educational System (CES) di gereja salah satu organisasi pendidikan agama yang berkantor pusat di wilayah gunung rocky menyatakan bahwa servant leadership mempunyai korelasi yang signifikan antara kepuasan kerja. Selanjutnya Amadeo (2008) penelitan yang dilakukan di Rumah Sakit juga menunjukkan bahwa servant leadership berhubungan terhadap kepuasan kerja. Hal ini juga didukung oleh Johnson (2008) penelitian di industri penerbangan di AS menyatakan bahwa servant leadership berhubungan terhadap kepuasan kerja. Kemudian Georgolopoulos, Papaloi \& Loukorou (2018) penelitian di sekolah menyatakan bahwa servant leadership berhubungan positif terhadap kepuasan kerja. Selanjutnya Akdol \& Arikboga (2017) penelitian pada perusahaan sektor Teknologi dan Informasi di Turkey menyatakan bahwa servant leadership mempunyai hubungan antara kepuasan kerja yang dimediasi oleh LMX (Leader Member Exchange). 
Hal serupa yang dilakukan oleh Mahdy, Harthi \& Din (2016) penelitian di salah satu sekolah di Oman menyatakan bahwa servant leadership berhubungan terhadap kepuasan kerja. Selanjutnya Mitterer (2017) penelitian di Rumah sakit menyatakan bahwa servant leadership mempunyai pengaruh terhadap kepuasan kerja, dan Guillaume, Honeycutt \& Austin (2013) penelitian yang dilakukan di salah satu universitas menyatakan bahwa servant leadership berpengaruh terhadap kepuasan kerja. Pada pengujian terakhir menunjukkan bahwa kepuasan kerja yang tinggi akan meningkat loyalitas karyawan, penelitian ini didukung oleh penelitian yang dilakukan oleh Noor \& Jamil (2014) di bidang sektor pemerintahan menyatakan bahwa kepuasan kerja karyawan mempunya pengaruh positif dan siginifikan terhadap loyalitas karyawan. Selanjutnya Hussain (2010) penelitian di perhotelan menyatakan bahwa kepuasan kerja karyawan mempunyai pengaruh terhadap loyalitas karyawan. Hal yang sama dilakukan oleh Lee (2008) penelitian di universitas menyatakan bahwa leadership empowerment mempengaruhi kepuasan kerja dan loyalitas karyawan, kepuasan kerja mepengaruhi loyalitas karyawan, dan Mitterer (2017) penelitian di Rumah sakit menyatakan bahwa servant leadership mempunyai pengaruh terhadap kepuasan kerja. Kemudian Onsardi, Asmawi \& Abdullah (2017) penelitian yang dilakukan di sektor pendidikan universitas menyatakan bahwa ada pengaruh positif kompensasi, empowerment, dan kepuasan kerja terhadap loyalitas karyawan, ada pengaruh positif kompensasi, dan empowerment terhadap loyalitas karyawan. Hal ini didukung juga oleh Frempong, Agbenyo \& Darko (2018) penelitian yang dilakukan di berbagai industri Pertambangan, Keuangan dan Manufaktur menyatakan bahwa kepuasan kerja mempunyai pengaruh yang siginifikan terhadap loyalitas dan komitmen.

\section{KESIMPULAN DAN SARAN}

\section{Kesimpulan}

Hasil yang dapat disimpulkan dari penelitian ini yaitu terdapat pengaruh servant leadership terhadap loyalitas karyawan, terdapat pengaruh servant leadership tehadap kepuasan kerja, dan terdapat pengaruh kepuasan kerja terhadap loyalitas karyawan.

\section{Keterbatasan Penelitian}

Keterbatasan

dalam penelitian ini mengacu terhadap kelemahan dalam penelitian ini. beberapa keterbatasan yang terdapat dalam penelitian ini yaitu penelitian ini hanya membahas sebatas variabel servant leadership, kepuasan kerja dan loyalitas karyawan. kemungkinan terdapat responden tidak mengisi dengan sesungguhnya atau hanya mengisi berdasarkan kondisi ideal yang diharapkan bukan kondisi sebenarnya.

3. Saran Untuk Penelitan Selanjutnya

Saran untuk penelitian selanjutnya penulis menyarankan untuk menambahkan variabel vang lain selain servant leadership, kepuasan kerja dan loyalitas karyawan, seperti kinerja 
karyawan, penelitian selanjutnya dapat dilakukan bukan hanya di industri manufaktur yang memproduksi sepatu saja, tetapi di industri manufakturlainya atau bidang yang lain.

\section{Implikasi Manajerial}

Peneltian ini bertujuan untuk mengatahui ukuran apa yang tepat untuk servant leadership dan untuk mengetahui pengaruh servant leadership terhadap loyalitas karyawan, pengaruh servant leadership terhadap kepuasan kerja dan pengaruh kepuasan kerja terhadap loyalitas karyawan. Kemampuan sesorang dalam mempengaruhi orang lain dengan bekerja sesuai dengan tujuan dan kerja sarna yang berlaku. Sebagai seorang pemimpin sudah umum diketahui bahwa gaya kepemimpinan yang dilakukan akan sangat mempengaruhi bagaimana perilaku karyawan untuk bekerja untuk sampai menuju tujuan yang sudah dibuat. Selain mempengaruhi bagaimana perilaku karyawan, pemimpin juga sudah pasti menguasai dan mengetahui hal-hal bagaimana mengatasi kepuasan kerja seorang karyawan dengan memberikan pasilitas kerja yang memadai, menjalin hubungan baik antara bawahan dan atasan, maupun antara karyawan. Impilkasi dalam penelitian ini servant leadership. Seorang memimpin harus mampu melayani bawahannya dengan cara menempatkan kebutuhan karyawan sebagai prioritas, pentingnya menghargai seseorang, dan membantu orang lain dalam mencapai tujuan. Prioritas seorang pemimpin adalah pada pengembangan karyawan yang menghasil nilai tambah karyawan dan meningkatkan kepuasan karyawan. maka sangat direkomendasikan kualifikasi pemimpin sebagai leadership seperti dapat menerima berbagai pendapat, mementingkan kepentingan bersama, mempunyai kasih sayang, pemberdayaan, mempunyai visi yang jelas, kerendahan hati, dan kepercayaan. Selanjutya, impilikasi manajerial yang digunakan dalam penelitian ini adalah kepuasan kerja, kepuasan kerja menjadi pusat perhatian yang harus diperhatikan oleh seorang pemimpin terutama perusahaan. Mengingat karyawan merupakan aset terpenting dalam perusahaan maka penting bagi perusahaan menjaga kepuasan kerja karyawan. karyawan yang merasa bahagia ditempat kerja akan memberikan dampak yang positif, sedangkan sebaliknya, karyawan yang tidak puas justru bisa menjadi ancaman bagi perushaan.kepuasan kerja tidak hanya didapat dari gaji dan tunjangan saja, tetapi ada banyak faktor yang berkontirbusi terhadap kepuasan kerja seperti hubungan baik antara atasan dan bawahan, fasilitas kerja yang mendukung, hubungan baik antara sesama karyawan, dan apresiasi kepada karyawan. sudah seharusnya seorang pemimpin dan manajemen menjadi salah satau tujuan perusahaan yang harus dicapai.

Implikasi manajerial lainya yang digunakan dalam penelitian ini adalah loyalitas karyawan, bagi perusahaan memperkerjakan karyawan yang memiliki loyalitas 
tinggi sangatlah menguntungkan, namun bagi perusahaan. Perusahaan yang baik akan memberikan ruang bagi karyawan untuk tumbuh dalam kariernya, seorang atasan yang baik cerdas akan mencari hal baru yang bisa dilakukan oleh karyawannya. Loyalitas akan dapat terus terjaga jika diberikan kesempatan untuk mengembang kemapuan dan tanggung jawab, jangan sampai memberi karyawan suatu pekerjaan diluar bidang yang ia minati. Pekerja harus didelegasikan degan baik agar setiap karyawan mendapat porsi dan bidangnya masing-masing. Kondisi perusahaan yang nyaman biasanya akan membuat loyalitas karyawan pada perusahaan akan meningkat.

\section{DAFTAR PUSTAKA}

Aaker, D. A. (1991). Managing Brand Equity: Capitalizing on the Value of a Brand Name.

Akdol, B., \& Arikboga, F. S. (2017). Leader Member Exchange as a Mediator of the Relationship between Servant Leadership and Job Satisfaction: A Research on Turkish ICT Companies. International Journal of Organizational Leadership, 6, 525-535.

Al-amri, M. S., Hajji, M. I. Al, \& Alawaji, A. S. (2016). The Relationship between Servant Leadership and Organizational Citizenship Behavior: An Empirical Study on Saudi Insurance Companies. International Journal of Business and Management, 11(11), 264-278.
Al-mahdy, Y. F. H., \& Al-harthi, A. S. (2016). Perceptions of School Principals ' Servant Leadership and Their Teachers , Job Satisfaction in Oman Perceptions of School Principals' Servant Leadership and Their Teachers, Job Satisfaction in Oman. Leadership And Policy In Schools, (May).

Alpern, R., Canavan, M. E., Thompson, J. T., McNatt, Z., Tatek, D., Lindfield, T., \& Bradley, E. H. (2013). Development of a brief instrument for assessing healthcare employee satisfaction in a low-income setting. PLoS ONE, 8(11), 1-9.

Amadeo, C. A. (2008). A Correlational Study Of Servant Leadership And Registered Nurse Job Satisfaction In Acute Health-Care Settings. University of Phoenix, (December).

Anderson, K. P. (2005). A Correlational Analysis Of Servant Leadership And Job Satisfaction In A Religious Educational Organization. University of Phoenix, (January).

Arif Noor, S. J. (2014). Factor Effecting Employee's Satisfaction and Employee's Satisfaction Contribution towards Employee's Loyalty in Public Sector Organizations of Pakistan. International Journal of Innovation and Applied Studies, 39(2), 242-252.

Asmawi, M., \& Abdullah, T. (2017). The Effect Of Compensation , Empowerment , And Job 
Satisfaction On Employee Loyalty. International Journal of Scientific Research and Management (IJSRM), 05(12), 7590-7599.

https://doi.org/10.18535/ijsrm/ v5i12.03

Aziri, B. (2011). Job Satisfaction : A Literatur Review. Management Research and Practice E, 3(4), 77-86.

Chauhan, V., \& Mahajan, S. (2013). Employer branding and employee loyalty in hotel industry. International Journal of Hospitality and Tourism Systems, 6(2), 34-43.

Chen, Y., \& Chen, H. (2016). Contributing Causes Of Employee Loyalty Of Service Personnel In The International Hotels. The International Journal of Organizational Innovation, 9(1), 107-119.

Danon Carter, T. B. (2014). The Influence of Servant Leadership on Restaurant Employee Engagement.pdf. J Bus Ethics.

Donghong, D., Haiyan, L., Yi, S., \& Qing, L. (2012). Relationship of servant leadership and employee loyalty: The mediating role of employee satisfaction. IBusiness, 4(3), 208-215.

https://doi.org/10.4236/ib.2012 .43026

Elegido, J. M. (2013). Does It Make Sense to Be a Loyal Employee? Lagos Business School, 116, 129.

Fawwaz, N., Qudah, A., Yang, Y., \& Anjum, M. A. (2018). Transformational Training Programs and Quality Orientation of Employees :
Does Employees ' Loyalty Matter? Sustainability, 10(2), 1-14.

Frempong, L. N., \& Agbenyo, W. (2018). The Impact of Job Satisfaction on Employees , Loyalty and Commitment: A Comparative Study Among Some Selected Sectors in Ghana The Impact of Job Satisfaction on Employees Loyalty and Commitment: A Comparative Study Among Some Selected Sectors in Ghana. European Journal of Business and Management, (May).

Georgolopoulos, V., \& Papaloi, E. (2018). Servant Leadership as a Predictive Factor of Teachers, Job Satisfaction. European Journal of Education, 8616(August), 15-28.

Giambatista, R., Mckeage, R., \& Mccormick, D. (2016). Servant Leadership and its Relationships with Core SelfEvaluation and Job Satisfaction. The Journal of Values-Based Leadership, 9(1). Guillaume, O., Honeycutt, A., \& Savage-austin, A. R. (2013). The Impact of Servant Leadership on Job Satisfaction. Journal of Business and Economics, 4(5), 444-448.

Haar, J. (2017). Work-family conflict and Employee Loyalty: Exploring the Moderating Effects of Positive Thinking Coping Work-Family Conflict. New Zealand Journal of Employment Relations, 42(1), 35-51.

HashimMuhammad, Muhammad Azizullah Khan, Mehboob 
Ullah, M. Y. (2017). Impact Of

Servant Leadership On

Employees' Loyalty Of Private

Universities Academicians In

Pakistan. City University

Research Journal, 96-111.

Heriyanti. (2015). Korelasi Antara

Kepemimpinan, Iklim

Komunikasai dan Kepuasan

Kerja Karyawan (Survei pada

Karyawan PT Kiwoom

Securities Indonesia).

Universitas Esa Unggul, 12,

95-114.

Hong Lu, Alison E. While, K. L. B. (2005). Job satisfaction among nurses: a literature review.

International Journal of Nursing, $\quad 31, \quad 630-638$. https://doi.org/10.1016/j.ijnurst u.2004.09.003

Hussain, R. I. (2010). The Linkage Of Employee Satisfaction And Loyalty In Hotel Industries Of Pakistan. Asian Economic and Financial Review.

Johnson, L. R. (2008). An Exploratory Study Of Servant Leadership, Emotional Intelligence, And Job Satisfaction Among High-Tech Employees. University of Phoenix, (August).

Jr, R. J. (2016). Job Performance, Job Satisfaction and Motivation: A Critical Review of Their Job Performance, Job Satisfaction , and Motivation: A Critical Review of their Relationship. International Journal of Advances in Management and Economics, (December).

Khuong, M. N., Linh, V. A., Duc, V. M., \& Leadership, A. E. (2015). The Effects of Transformational and Ethics-
Based Leaderships on Employee' s Loyalty towards Marketing Agencies in Ho Chi Minh City , Vietnam. International Journal of Innovation, Management and Technology, 6(3).

Kowalik, J. L. (2013). The Influence Of Position Type And Generational Grouping On Job Satisfaction Of Milwaukee County , S Public Health Workforce. University of Wisconsin-Milwaukee, (December).

Lee, S. S. (2008). Relationships among leadership empowerment, job satisfaction , and employee loyalty in university dining student workers. Iowa State University, 9(3), 28-38.

Maqsood Haider, Sajjad Ahmad Afridi, Farman, S. (2019). Servant Leadership and Faculty Loyalty Nexus; Mediating Role of Faculty Trust. NUML International Journal of Business \& Management, 14, 60-74.

Marcelino, A. R., \& Correia, M. F. (2015). This research has been supported by a grant from Instituto Nova Forum. I gratefully acknowledge the people at Novabase who participated in this study, especially Álvaro Ferreira. I am grateful to Ana Regina Marcelino for her collaboration during data coll. Universidade Nova de Lisboa, 1-32.

Meria, L. (2018). Pengaruh Konflik Pekerjaan Keluarga dan Kepuasan Kerja terhadap Komitmen Organisasional. 
Universitas Esa Unggul.

Meria, L. (2019). Mengukur Dampak Job Insecurity Terhadap Turn Over. Universitas Esa Unggul, (1978).

Michael Nippa, T. H. (2014). Is Employee Loyalty Research Living In The Shadows? Consolidating Findings Into A Future Research Agenda. Chair of Management, Leadership, and Human Resources Faculty of Business Administration, 151.

Mitterer, D. M. (2017a). Servant Leadership and Its Effect on Employee Job Satisfaction and Turnover Intent. Walden University.

Mitterer, D. M. (2017b). Servant Leadership and Its Effect on Employee Job Satisfaction and Turnover Intent.

Moyes, Glen D Lawrence P. Shao, M. N. (2008). Comparative Analysis Of Employee Job Satisfaction In The Accounting Profession. Journal of Business \& Economics Research.

Nuijten, Dirk van Dierendonck, I., \& Published. (2011). The Servant Leadership Survey: Development and Validation of a Multidimensional Measure. $J$ Bus Psychol (2011), 219(4), 217-223.

Nwachukwu, C., Chládková, H., \& Olatunji, F. (2018). The Relationship between Employee Commitment to Strategy Implementation and Employee Satisfaction. Trends Economics and ManagemenT, 8527(1), 45-56.

Odebiye, Olauye, O. (2013). Exploring the Relationship between Job Satisfaction Dimensions and Organizational Commitment among Nigerian Banks Employees. International Journal of Academic Research in Economics and Management Sciences, 2(6), 85-95.

Pandey, Chetna, R. K. (2012). Impact Of Job Satisfaction And Organizational. International Journal of Social Science \& Interdisciplinary Research, 1(8).

Prudon, P. (2015). Confirmatory factor analysis : a brief introduction and critique. Ammons Scientific, (July).

Rojuaniah. (2017). Kepuasan Kerja sebagai pendorong Komitmen Organisasional dan Organizational Citizenship Behavior (OCB). FEB Universitas Esa Unggul.

Sachin Murali, Aayush Poddar, A. S. (2017). Employee Loyalty , Organizational Performance \& Performance Evaluation - A Employee Loyalty , Organizational Performance \& Performance Evaluation - A Critical Survey. IOSR Journal of Business and Management, (August).

Stephen P. Robbins, T. A. J. (2015). Organizational behavior. New Jersey: Pearson Prentice Hall.

Sugiyono. (2012). Metode Penelitian Kuantitatif, Kualitatif, dan R\&D. Bandung: Alfabeta, 2012.

Tanujaya, W. (2012). Hubungan Kepuasan Kerja Dengan Kesejahteraan Psikologis (Psychological Well Being) Pada Karyawan Cleaner. 
Universitas Esa Unggul, (November 2011).

Tanujaya, W. (2014). Hubungan Kepuasan Kerja Dengan Kesejahteraan Psikologis (Psychological Well Being) Pada Karyawan Cleaner (Studi Pada Karyawan Cleaner Yang Menerima Gaji Tidak Sesuai Standar Ump Di Pt. Sinergi Integra Services, Jakarta). Psikologi, Universitas Esa Unggul, (November 2011).

Vahid, D. (2019). T The Relationship Between Job Satis Faction And Employees , Loyalty: An Iranian Case Study. CrossCultural Management Journal, XXI(1), 67-73.
Wan, H. L. (2007). Employee Loyalty at the Workplace: The Impact of Japanese Style of Human Resource Management. International Journal of Applied HRM, 3(1), 1-17.

Woodruff, T. R. (2004). Executive Pastors' Perception Of Leadership And Management Competencies Needed For Local Church Administration. Southern Baptist, 22(Nos 4/5), 247-256.

Yulianto, A., \& Martina, D. (2018). Hubungan Iklim Organisasi Dan Loyalitas Karyawan Pada Sebuah Perusahaan ECommerce Di Jakarta. Universitas Esa Unggul. 